\title{
Material Details in Edith Wharton's Writings
}

\author{
Almasa Mulalić*
}

\begin{abstract}
Edith Wharton was among the most prominent writers of her time and could compete with any of her contemporary colleagues. However, she as a female writer rose above her colleagues in her style and attitudes towards novel writing. The central themes in her novels were the conflict between social and individual fulfillment, repressed sexuality, and the manners of old families and the new elite, who had made their fortunes in more recent years. The contradictions in the upper class society were yet another theme that intrigued Wharton. The question of what is moral to one part of the society did not necessarily mean that it is moral for the other part of the society. Some people could at that time escape without any hidden or open punishment from the rest of the society if they were enough skillful and clever. On the other hand, for some people it was difficult to avoid pressure from the society and behave according what their mind and heart were telling them. This paper in particular deals with the Wharton's biographical background with the special attention to her family and life experience and how it influence and shaped her style of writing. The paper also deals with material and graphic details in her novels and the reasons behind usage of those graphic details. Wharton's novel The Age of Innocence is still one of the most read novels and is required reading in High Schools and at the Universities. The final part of the paper deals with the abovementioned novel that influenced and shaped the writings of the generations of writers after her death.
\end{abstract}

Keywords: material details, upper-class society, style of writing, morality, manners of old families

\footnotetext{
Corresponding author: Almasa Mulalić, Faculty of Arts and Social Scinces, International Sarajevo University, Bosnia Herzegovina, e-mail: amulalic@ius.edu.ba
} 


\begin{abstract}
The impression produced by a landscape, a street or a house should always, to the novelist, be an event in the history of a soul, and the use of the 'descriptive passage' and its style should be determined by he fact that it must depict only what the intelligence concerned would have noticed, and always in terms within the register of that intelligence (from "Constructing a Novel", Part IV in The Writing of Fiction)
\end{abstract}

\title{
Introduction
}

Edith Wharton was one of the most prominent writers, whose works were extensively tackling the effect of a social class on behavior and mind, especially that of the upper class elite. In the process of expressing and articulating American progressive ideals, Wharton was also addressing European customs, morality and sensibility. Therefore, as it will be explored in the paper, Wharton was the product of both cultures/civilizations and at the same time was able to write and earn a living from her literary writings. Wharton had an impressive forty years career during which she published more than forty books. Some of her works include The Decoration of Houses (1897), The Greater Inclination (1899), The House of Mirth (1905), The Valley of Decision (1905), Ethan Frome (1911), The Custom of the Country (1913), The Age of Innocence (1920), A Backward Glance (1934) and The Buccaneers (1938).

Beginning from her early childhood Wharton wrote stories and according to many of her admirers she had an innate ability to attract her reader's attention with her skillful expressions throughout her literary works. Her novels were celebrated and admired at the time when she was alive as they are celebrated today for their vivid setting, satiric wit, ironic style and moral seriousness. Besides, her literary characters were often presented as tragic victims of cruel social convictions. She, in a way, criticized double standards in the upper class society at that time. Through her novels she tried to present the society as it really is, and didn't try to idealize behaviors and attitudes of the proponents in her writings. There is one characteristic in her writing that attracts our attention as readers, the small details that she is particularly paying attention throughout her writing. Therefore, this paper deals with Wharton's emphasis on the material details. As a writer Wharton was 
immediately recognized by the readers as being very skillful in presenting her literary phenomenon by using tinny details.

In order to analyze and discuss the main research question mentioned above, this paper explores Wharton's biographical background and her milieu that inevitably played significant role in her literary style of writing. Then, the greatest novelty in Wharton's novels was using of architecture and material details, which is the subject of the second part of this paper. Finally, this paper also makes an extensive analysis of Wharton's using of material details in The Age of Innocence, by special emphasis on the internal and external literary influences on her style of writing.

\section{Wharton's Biographical Background and Literature}

Edith Wharton (1862-1937) was born during the Civil War and certain historical, socio-political and economic developments played significant role in her writings. There are several periods that left significant impact on her writings namely; the Gilded Age, the Progressive Era, the WW I and the Great Depression. Immediately after the end of the Civil War, America began with the process of political, social and economic reconstruction and in the course this led to the territorial expansion and eventually imperialism. However, rapid economic and industrial growth, urbanization, mass migrations and technological inventions affected all aspects of life, including the scope of the literature, as is the case with Wharton's novels. Therefore, these socio-political and economic transformations had stimulated the emergence of a vast literature on race, slavery, discrimination, segregation, children, women and worker's rights. Some of the most influential writers on these themes include Herbert Gutman, Leon Litwack, John Hope Franklin, Eugene Genovese, Elizabeth Fox-Genovese, Eric Foner and Kenneth Stampp.

Then, around the turn of the century, the Progressive Movement began to respond to the challenge of industrialization, urbanization and immigration. Literary works that dealt with these issues included Jack London, The Iron Heel, Ignatius Donnelly Caesar, Column, Jacob Riis, How the Other Half Live, Stephen Crane Maggie, A Girl of the Streets, W. T. Stead, If Christ Came to Chicago, Henry James, The Bostonians, 
Mark Twain, Huckleberry Finn and William Dean Howells, Rise of Silas Lapham. Then, the WW I and the Great Depression also left significant mark on the writings of Wharton. The years after the "war to end all wars" [Woodrow Wilson] were characterized by social unrest and violence, economic problems and high inflation, labor unrests and strikes, fear of immigrants and communism, racial tensions and riots, prohibition and gangsters. See history of these periods in Philip Jenkins (1997), A History of the United Sates, New York: Palgrave Macmillan, pp. 147214; Alan Brinkley (1997), The Unfinished Nation: A Concise History of the American People, New York: The McGraw-Hill Companies, Inc., pp. 487-528 and 581-603. All this historical developments in the society had a great influence on Wharton's literary evolution.

Edith Wharton (1862-1937) was born in New York in an aristocratic family (many writers wrote about her biography and among them are Grace Kellogg Griffith, The Two Lives of Edith Wharton: The Woman and Her Work (1965); Millicent Bell, Edith Wharton and Henry James: The Story of Their Friendship (1965); Blake Nevius, Edith Wharton: A Study of Her Fiction (1953); Irving Howe, Edith Wharton: A Collection of Critical Essays (1962) and Louis Auchincloss, Edith Wharton: A Woman in Her Time (1971). and they expected from her to learn and uphold aristocratic norms and values. Therefore, her father made a decision to educate her privately at home with the help of the skilful tutors and she was also educated abroad. Her family set up certain aristocratic standards and her family was well known by those standards. Thus, her family, as many other aristocratic families in America, was characterized with the wealth, power, social standing, connections and family bloodlines. Wharton's aristocratic background played significant role in her writings as she was in a position to present literary aspects from different, insider's and outsider's perspectives. This is especially significant because Wharton later rebelled against her exclusive aristocratic and wife's role in a patriarchal society. In this regard, many writings signal out Wharton as one of the early promoters of feminism. (Lekesizalin, 2008).

Besides her passion for writing Edith Wharton had a lifelong passion for travel, gardening, art, and interior decoration. Therefore, 
European impact and experiences were reflected in all her novels, especially in the form of using material details in the literature. For instance, her first book, The Decoration of Houses (1898), was based on a study of French architectural design. Similarly, Wharton had a great love of architecture, gardens and design and, thus, wrote numerous articles and essays on these subjects including Italian Villas and Their Gardens (1904). She often traveled with Henry James to Europe, where she was observing European culture by combining it with the American ones. Them, in her writing Wharton looked at the proponents of her novels as decisive and humorous and, as well as, at their socialpsychological insights. Therefore, direct personal experience and sociohistorical developments played significant role in Wharton's writings.

Wharton's writings have many similarities with the writing of Henry James, although she tried to use her distinctive style in writing, which is neither European nor American. Therefore, James and Wharton were often explored in the comparative literature. As the author of numerous best-selling award-winning works including novels, short stories and travel essays Wharton has inspired many other authors. Some of her works were adapted to the stage and film and many are still in print today. Therefore, her works were extensively used because:

Wharton developed the keen observational skills and distanced, often ironic perspective that distinguish her social satires. She also acquired early on a sense of history and a visual approach to literature and landscape. Place whether it be New York City transforming itself from small town to major metropolis, New England blanketed with snow, or elegant brownstone interiors is the dominant metaphor in Wharton's fiction ( Singley, 2003).

Wharton in her novels was concerned with social mores and social reform, which reflected the extremes and anxieties of the Gilded Age. For that reason Wharton's use of material culture also reveals the social and psychological realities of her female characters. In addition, Wharton's detailed accounts of late nineteenth and early twentiethcentury life in forms of communication, transportation, architecture and design offer important clues to the dispositions and fates of her heroines. Trains, carriages, steam-liners, electric currents, and clocks, for example, all underline the quickening pace of modern life and its pressures. Of 
particular importance was fashion, a marker that allows Wharton to trace women's shifting social positions (Singley, 2003).

\section{Architecture and Wharton's Material Details Style}

In the above parts of the paper, an emphasis was placed on the role of biography, history, politics and socio-economics in literary Wharton's writing. This part of the paper aims to conceptualize literary approaches in the literature, namely realism, and naturalism that partially shaped Wharton's literary works. However, special emphasis will be placed on an analysis of Wharton's style of writing characterized by material details, which was perhaps derived from arts and architecture. There is also a feeling that Wharton was aware of unusual and superficial attitudes in the society at that time. The fact that the women of that time would order the dress from Europe and wait until next year to get the chance and wear it was at least unexpected, but this was the practice in the society. Most probably the woman at that time thought that it was exciting to have the dress in the wardrobe hanging there for one year and wear it in the next season. Arts and architecture is furthermore associated to realism that is "in general, writing or art that appears to accurately record life, especially everyday or ordinary life. As a trend in European literature it is particularly associated with the mid-nineteenth century novel of middleclass life, pioneered by the French novelists Honoré de Balzac (1799-1850) and Gustave Flaubert (1821-1880), and the English novelist George Eliot (1819-1880)" (Beasley 2007). Therefore, realism as "the faithful representation of reality" and naturalism as "an application of scientific natural principles on the study of human beings and social phenomenon," were used by Wharton in her novels.

The Decoration of Houses (1897) was written in collaboration with Ogden Codman. And is indeed a particular characteristic of Wharton's artistic enterprise. Therefore, Wharton's writing style and her ability to present scenery, landscape, interior and even the way people were dressed in such details could also be closely related to her background and her interest in architecture. 
This work was presentation of interior design, which also influenced her later literary works and material detail style in terms of the description of houses, rooms, furniture and fabrics. In The Decoration of Houses Wharton insisted on the structural relationship between the private inside of a home and its public façade (Kinmen, 2000). In this work Wharton always draws a line between how the houses of her characters were decorated in relation to the emotional feelings of her characters. According to Ellen Eva Frank in the nineteenth century architects began conceiving buildings as 'books which can be read' (Stephenson, 2010).

In another work Writing of Fiction, Wharton writes about Honore de Balzac as the first novelist who investigated the 'relation of his characters to their houses (Stephenson, 2010). Wharton follows de Balzac and similarly envisioned literature as an architectural or constructed space. Balzac's endless curiosity about specificities of business and legal transactions, property rights and the art of decoration is very similar to Wharton's passion for details of customs and décor and her particularity of the manners of her society. Therefore, Rubin states that "it is difficult to conceive of The Age of Innocence ever having been written without the fruitful examples of the great French novelist" (Rubin, 1957).

There are many examples in Wharton's novels where windows, thresholds, libraries and other interior space play very important illustrative part. For instance, in The Age of Innocence Archer is most of the time portrayed in his library as "a vigilant hand had, as usual, kept the fire alive and the lamp trimmed; and the room with the rows of books, its bronze and steel statues of "The Frences" on the mantelpiece and its many photographs of famous pictures, looked singularly home-like and welcoming" (Wharton, 2005). This description reveals some particular characteristics of Newland Archer which is a passion for reading. From the description it is clear that the house owner is most probably a passionate reader and educated man. Then, photographs of the famous people on the wall indicate his artistic inclination. At the same time Archer belonged to the upper class society and with a sense of elite constrains of that time. Then, diverse and unique furnishing in Ellen's New York flat differentiates her as free women without elite constrains. 
Finally, Archer sees her apartment as "small slender tables of dark woods, a delicate little Greek bronze on the chimney-piece, and a stretch of red damask nailed on the discolored wallpaper behind a couple of Italian-looking pictures in old frame"(Wharton, 2005). By describing her apartment in such a way it is obvious that the person living there is someone special and different than some other characters in the novel.

Wharton clearly distinguishes Ellen from the other characters in the novel. Ellen is presented as different and without any constrains towards the accepted norms of the society. Therefore, by using architectural details Wharton describes her apartment, giving it a touch of particularity and specificity affiliated to the person living there. Then, Wharton's description of van der Luydans drawing room is also very typical to her architectural details style of writing. She describes drawing room as "high-ceiling white-walled Madison Avenue drawing-room, with the pale brocaded armchairs so obviously uncovered for the occasion, and the gauze still veiling the ormolu mantel ornaments and the beautiful old carved frame of Gainsborough's "Lady Angelica du Luc"(Wharton, 2005).

The above analysis and examples indicate Wharton's extensive using of architectural details in literary writing. The details that she envisioned and skillfully presented to the reader are on a very high level of architectural competency. Indeed, if she was not so keen in using architecture, her novels would, most probably, be less sophisticated and written in a less fissionable manner. Therefore, Wharton's architectural details could be used by contemporary writers especially in view of the fact that contemporary architecture seeks such literary explorations.

\section{Psycho-Sociological Aspects of Wharton's Material Details}

Wharton used extensively technical terms and images from sociology and anthropology that were emerging as a new field of study at that time. In The Age of Innocence the opening scene communicates more about characters than one may notice. Throughout the description Wharton brings to the reader social world wealthy people of that time. Those small details are so important to Wharton that she opens up a novel 
with the scene in which everyone is dressed in their best clothes. Furthermore, the fact that lady from the upper class of New York kept their dresses, ordered from the most prestigious shops in the Europe, untouched in their wardrobes over one year, show the sophistication and attitudes of those people. This, without any doubt prepares readers for the dramatic settings in the novel. Although the narrator does not tell as explicitly about the character's attributes, we learn about them from the descriptions of the place and how they are dressed. Narrator at the opening of the novel talks about Opera House envisioned with splendor and costliness that could match even those of great European capitals. The following passage illustrates social aspects of characters that are described by material details:

Though there was already talk of the erection in remote metropolitan distance "above the Forties" of a new Opera House which should compete in costliness and splendour with those of the great European capitals, the world of fashion was still contend to resemble every winter in the shabby red and gold boxes of the sociable old Academy (Wharton, 2005).

Wharton was writing about the world that had undergone significant changes and transformations. Likewise, Wharton compared European and American cultures, the elite aristocratic families and common day-to-day socio-cultural problems. According to her writings, the elite of that time lived outside of reality of the world. Therefore, some historical events had played a part in her choices in writing while others did not. Wharton worked as a front line correspondent and charity volunteer during WWI, spending several years in France. A Son at the Front (1922) is Wharton's full length novel about World War I (Benert, 1996).

Wharton's writings were also influenced by the Victorian Era. Wharton inherited a domestic, often sentimental, literary tradition from Harriet Beecher Stowe, Louisa May Alcott and Sarah Orne Jewett. She acknowledged her debt to these writers but rejected the "rose-colored" lenses through which they saw the world because Wharton was instead interested in moral depth (Wharton, 2005). Therefore, due to her originality Wharton helped to transform nineteenth-century romantic literature into a twentieth-century realism that confronted directly and 
critically the pressing issues facing men and women at the turn of the century.

Material details in Wharton's novels establish historical accuracy and differentiate the Old New York and the Modern world. In The Age of Innocence Wharton directly leads the reader towards future urban, demographic and social changes of the New York. Therefore, this novel is product of Wharton's life experience. In this regard, she once stated: "I found a momentary escape in going back to my childhood memories of a long vanished America, and wrote The Age of Innocence." According to Singlay:

Wharton is by critical and popular acclaim one of the United States' finest novelists and short story writers. A consummate stylist and astute critic of late nineteenth and early twentieth-century American social life, Wharton often ridiculed the upper-class New York society of which she herself was a member. She also turned her sharp eye to New England and Europe, creating incisive portraits of characters deeply affected by their social and physical environments. Wharton's ability to combine such cutting satire and irony with compassion for human suffering results in a unique American realism that elevates her characters' struggles against restrictive conventions and circumstances beyond comedy of manners to pathos, and even tragedy (Singley, 1957).

Moreover, Wharton was interested in the characteristics of human being and how they connect and react to certain situations, including effects of class on the behavior and the consciousness. Wharton examines upper class value and morals in all their convention and tradition, rigidity and hypocrisy, often with delicate sarcasm and humor. Therefore, one has to look into material details, which Wharton was using skillfully and accurately, which portray upper class morals and values as hypocritical and insincere. Wharton's using of material details in describing social aspects of life is evident in many passages. For instance, Newland Archer is represented as an intellectual and cultural embodiment of freedom in contrast to the narrow confines of New York society. Then, his love towards Ellen is presented as an escape from social hypocrisy and artifice to which he feels trapped. Therefore, in Ellen he seeks an intellectual and cultural freedom from the shallow restrictions of New York society. However, Wharton being artistically shaped in such a way ensures that her character Newland's social circumstance will never allow him to 
escape from the rules of his society. Finally, Newland realizes that their society is "self deluded and deeply hypocritical" and "our law allowed divorce but our society does not"(Wharton, 2005).

As Wharton became even more popular her readers recognized that simply a person having an opera seat spoke loudly about herlhis social status. Her capability to overwhelm reader with the details in her novel, and making every detail meaningful made her writing even more interesting. As she had an American and European personas, she made a commitment to the values of New York at the time of her parents day and on the other hand her need for the acceptance and creativity of new order. For instance, in Wharton's description of Ellen's clothes she depicts her personality. Her clothes are usually flowing and dark, while on the other hand May's fair hair braided and her dress is made of "tulle tucker." May thoroughly followed the rules of the society and did all to appear completely innocent. She usually wears white dresses; her hair is always firmly in place and she is even presented to blush when necessary. All these details indicates that Wharton was deeply connected to her characters from the novels, she wanted readers to feel and sense the emotions inside each of her characters and she succeeded in that effort by offering her readers detail insights and feelings of her main proponents by presenting them as visible and real.

\section{Concluding Remarks}

There are many critiques, interpreters, scholars and man of pen who had criticized Wharton and her style of writing. Apparently, they criticized Wharton's excessive emphasis on an elite people of that time and her significant neglecting of ordinary people. Nevertheless, she was, without any doubt, one of the most prominent writers of the $19^{\text {th }}$ century who had a great influence on the generations of writers to come. In particular Wharton's skilful using of material details in describing natural, material and psycho-social aspects of life was the greatest novelty of her literary writings.

The main objective in Wharton's writing was the representation of characters by means of situation whereby vivified and enlightened by 
infrequent creative illustrations straight literal method was applied. Wharton belonged to a group of writer we call romantic-realistic and, therefore, her writings also signify moral, social and educational lessons. In this regards, after reading her novels, readers like me are often left with many questions. Wharton's novels are not classical romance novels with the happy ending, but there are always social constrains that the main proponents go through and are unable to brake out from those constrains.

This paper pointed out the above particular characteristics of Wharton's literary writings, with special emphasis on her novel The Age of Innocence. The paper reaffirmed the role of life experience, arts and architecture, psychological, social and natural aspect of life in the process of literary writing. Wharton's using of material details in her novels was extensively discussed and analyzed by considering these aspects of life and literary writings. This in turn answers our main question why Wharton used so many material details in her novels. 


\section{References}

Beasley, R. (2007). Theories of Modern Poetry. New York: Routledge. Benert, A. L. (1996). "Edith Wharton at War: Civilized Space in Troubled Times." Twentieth Century Literature, Vol. 42, No. 3, pp. 322-343.

Brinkley, A. (1997). The Unfinished Nation: A Concise History of the American People. New York: The McGraw-Hill Companies, Inc..

Jenkins, P. (1997). A History of the United Sates. New York: Palgrave Macmillan.

Kinmen, A. H. (2000). "The Making of Professional; Edith Wharton's The Decoration of Houses." South Atlantic Review, Vol. 65, No. 1, pp. 98-122.

Lekesizalın, F. (2008). "Feminist Perspectives in Edith Wharton and Reşat Nuri Güntekin: a Comparative Study of the House of Mirth and Çalıkuşu." Social and Applied Science, Vol. 3, No. 6, pp. 1118.

Liisa, S. (2010). “ Decorating Fiction: Edith Wharton's Literary Architecture." University of Toronto Quarterly, Vol. 79, No. 4, pp. 1096-1104.

Rubin, L. (1957). "Aspect of Naturalism in Four Novels by Edith Wharton." Twentieth Century Literature, Vol. 2, No. 4, pp. 188.

Singley, C. J. (2003). A Historical Guide to Edith Wharton. New York: Oxford University Press.

Wharton, E. (2005). The Age of Innocence. San Diego: ICON Group International, Inc. 